\title{
SPOŁECZNE BUDOWNICTWO MIESZKANIOWE WOBEC STARZENIA SIĘ POLSKIEGO SPOLECZEŃSTWA*
}

\section{WPROWADZENIE}

Starzenie się populacji Polski stawia przed społeczeństwem szereg wyzwań, a od możliwości sprostania im zależeć będzie poziom i komfort życia przyszłych pokoleń seniorów. Można wyróżnić kilka podstawowych kwestii, które stają się wyzwaniem dla polityki społecznej w związku z procesem starzenia się populacji. Wzrost liczby osób starszych przełoży się na wzrost zapotrzebowania na świadczenia opiekuńcze realizowane przez podmioty sektora ochrony zdrowia oraz pomocy społecznej. Wydatki na świadczenia opiekuńcze na rzecz niesamodzielnych osób starszych będą rosły, ale w stopniu niewystarczającym do zabezpieczenie potrzeb osób niesamodzielnych. Można spodziewać się ograniczeń w dostępie do usług sektora ochrony zdrowia i pomocy społecznej. Większy udział osób w wieku poprodukcyjnym w populacji wpłynie na wydolność obecnego systemu emerytalnego opartego na zasadzie solidarności międzypokoleniowej. Wysokość uzyskiwanych świadczeń emerytalnych wyliczana będzie na podstawie zgromadzonego kapitału w okresie aktywności zawodowej. Według prognoz ekonomicznych w kolejnych dekadach spodziewać się można wzrostu liczby osób, które będą uzyskiwały dochód poniżej emerytury minimalnej ${ }^{1}$.

Chociaż przywołano tylko dwie z wielu kwestii społecznych, jakie dotyczyć będą Polski w związku z procesem starzenia się jej populacji, należy zwrócić szczególną uwagę na możliwość zaspokojenia potrzeb z kategorii podstawowych, do których zaliczyć możemy potrzeby mieszkaniowe. Celem artykułu jest podjęcie rozważań nad sposobami zaspokajania potrzeb mieszkaniowych osób starszych, w tym niesamodzielnych, przez władze samorządowe. Przedstawiono więc $\mathrm{w}$ nim informacje dotyczące starzenia się populacji w kontekście sytuacji mieszkaniowej osób starszych, w szczególności osób, które wymagaja pomocy i wsparcia w codziennym funkcjonowaniu. Poruszone zostały kwestie zwiazane ze znaczeniem społecznego budownictwa mieszkaniowego w kontekście starzejącej się populacji. W pracy zastosowano metodę desk research,

* Część informacji zawartych w artykule pochodzi z badań realizowanych w ramach projektu pt. „Społeczne budownictwo mieszkaniowe i jego rola w zaspokajaniu potrzeb mieszkaniowych niezamożnych gospodarstw domowych w Polsce" finansowanego ze środków Narodowego Centrum Nauki (2014/13/N/HS4/02100).

${ }^{1}$ M. Bieliecki, K. Makarski, J. Tyrowicz, Co doktadnie oznacza obniżanie wieku emerytalnego w Polsce, Warszawa 2016. 
analizy danych zastanych opracowanych przez krajowe i międzynarodowe instytucje statystyczne oraz materiałów opracowanych przez władze samorządowe, które przygotowały je na potrzeby prowadzonego przez autorów studium przypadku. Przedstawiono również przykłady przeprowadzonych inwestycji w zakresie budownictwa senioralnego w Poznaniu, Szczecinie i Warszawie.

\section{SYTUACJA DEMOGRAFICZNA - STAN OBECNY ORAZ PROGNOZY}

Wzrost liczby osób starszych w populacji nie ma wymiaru negatywnego, lecz oznacza, że dana populacja osiaggnęła poziom rozwoju umożliwiający zdecydowanej większości przeżycie co najmniej 70, 80, a coraz częściej nawet 100 lat. Wzrost liczby seniorów w populacji jest zjawiskiem typowym dla krajów wysoko rozwiniętych i rozwijających się. Prócz wzrostu średniej długości życia następuje również odejście od modelu reprodukcji rozrzutnej do modelu oszczędnego, co w przypadku zdecydowanej większości krajów OECD powoduje, że współczynnik dzietności kształtuje się na poziomie poniżej progu dającego szansę na osiągnięcie stanu zastępowalności pokoleń, czyli 2,10-2,15 dziecka na kobietę w wieku rozrodczym. W połowie drugiej dekady XXI w. współczynnik dzietności w Polsce wynosił zaledwie 1,32, w przypadku krajów Unii Europejskiej niższy odnotowano tylko w trzech państwach: Portugalii, na Cyprze i w Grecji². W 1990 r. niemal co trzeci mieszkaniec Polski był w wieku przedprodukcyjnym, natomiast w 2016 r. ich udział zmniejszył się do zaledwie $18 \%{ }^{3}$. Nawet najbardziej optymistyczne prognozy nie przewidują znaczącego odwrócenia się obecnych trendów demograficznych w zakresie dzietności i osiagnięcia współczynnika dzietności gwarantującego zastępowalność pokoleń ${ }^{4}$.

W 2016 r. populacja Polski liczyła ponad 38,4 mln osób, według prognoz zaś w 2050 r. ulegnie zmniejszeniu do $33,9 \mathrm{mln}^{5}$. Jest to trend demograficzny charakterystyczny dla krajów europejskich. Europa będzie jedynym kontynentem, co do którego demografowie przewidują zmniejszenie liczby ludności. W przypadku Polski, oprócz aspektów związanych z niskim współczynnikiem dzietności, ważny jest również czynnik migracyjny, szczególnie w zakresie migracji długoterminowych zewnętrznych. Jeśli utrzymają się obecne trendy migracyjne, można się spodziewać, że prognozy demograficzne w zakresie liczby ludności okażą się przeszacowane i liczba ludności Polski w kolejnych dekadach będzie jeszcze niższa.

W wymiarze krajowym osoby starsze (według kryteriów ekonomicznych mężczyźni w wieku 65 i więcej lat oraz kobiety powyżej 60 roku życia)

\footnotetext{
${ }^{2}$ GUS, Sytuacja demograficzna Polski na tle Europy, Warszawa 2017.

${ }^{3}$ GUS, Dane ostateczne za 2016 rok dotyczqce wyników bieżacych badań demograficznych, Warszawa 2017.

${ }^{4}$ GUS, Prognoza demograficzna na lata 2014-2050, Warszawa 2014.

${ }^{5}$ Ibidem.
} 
w 2016 r. stanowiły 21,2\% populacji. W ujęciu regionalnym najmłodszym województwem jest podkarpackie, w którym seniorzy stanowili w analizowanym roku 18,7\% populacji. Natomiast najwyższy odsetek osób starszych był w województwie łódzkim - 22,5\% ${ }^{6}$. W 2050 r. według prognoz demograficznych osoby starsze będą stanowiły nawet $36,5 \%$ populacji. Najwyższy odsetek osób $\mathrm{w}$ wieku senioralnym będzie $\mathrm{w}$ województwie opolskim - 40,2\%, natomiast najmłodszą populację będzie miało województwo pomorskie - 33,7\% ${ }^{7}$. Zauważalna jest zależność pomiędzy potencjałem gospodarczym regionu a liczba seniorów w populacji.

Średnia długość życia kobiet w Polsce wynosi około 81,5 roku, a mężczyzn przeszło 73 lata $^{8}$. Prognozy demograficzne zakładaja, że do 2050 r. kobiety w Polsce będą żyły średnio około 88 lat, a mężczyźni co najmniej 81 lat. Utrzymywać się będą różnice w długości życia pomiędzy płciami, co skutkować będzie feminizacją starości, czyli przewagą kobiet w stosunku do liczby mężczyzn, szczególnie w kategorii wiekowej 85 i więcej lat ${ }^{9}$. Średnia długość życia zróżnicowana jest również ze względu na miejsce zamieszkania, w przypadku mieszkańców obszarów wiejskich prognoza w zakresie trwania życia jest kilka miesięcy lub lat krótsza. Różnice pomiędzy długością życia mieszkańców miast a obszarów wiejskich mogą wynikać m.in. z charakteru wykonywanej pracy, dostępności do usług świadczonych przez sektor ochrony zdrowia, szczególnie usług realizowanych przez lekarzy specjalistów. Ponadto wzrastać będzie liczba jednoosobowych gospodarstw domowych prowadzonych przez osoby starsze, szczególnie w wieku 80 i więcej lat.

\section{POTRZEBY MIESZKANIOWE SENIORÓW}

Prognozy demograficzne skłaniają do podjęcia rozważań nad potrzebami mieszkaniowymi osób starszych, szczególnie w wieku 85 i więcej lat (tzw. starości sędziwej) oraz sposobami ich zaspokojenia w ramach systemu budownictwa społecznego. Warto pokreślić, że osoby starsze nie stanowią grupy jednorodnej. Potrzeby seniorów w zakresie mieszkaniowym są zróżnicowane, w tym z uwagi na sytuację ekonomiczna, społeczna, psychologiczna, biologiczną, w szczególności ze względu na stopień samodzielności.

W ujęciu całościowym możemy wyróżnić dwie główne grupy seniorów podczas analizy potrzeb mieszkaniowych. Pierwszą stanowią osoby, które pomimo zaawansowanego wieku (nawet stulatkowie i superstulatkowie) cechuje wysoki stopień samodzielności. W przypadku tej grupy osoby starsze potrzebują jedynie przystosowania mieszkania oraz budynku, aby poprawić komfort i bezpieczeństwo życia. W wielu przypadkach wystarczy przystosować sanitariaty, aby zminimalizować ryzyko upadku (np. podczas wychodzenia z wanny)

\footnotetext{
${ }^{6}$ GUS, Powierzchnia i ludności w przekroju terytorialnym 2017, Warszawa 2017.

7 GUS, Prognoza demograficzna na lata 2014-2050, Warszawa 2014.

8 Ibidem.

9 Ibidem.
} 
lub usunąc z budynku mieszkalnego główne bariery architektoniczne. Warto również zwrócić uwagę na tzw. syndrom czwartego piętra. W przypadku wielu bloków wybudowanych w XX w. brakuje wind w budynkach czteropiętrowych i wyższych. W przypadku lokali umieszczonych na wyższych piętrach seniorzy ze względu na osłabienie narządów ruchu, co jest procesem typowym w okresie starości, mogą zostać unieruchomieni w swoich mieszkaniach. Pokonanie kilku kondygnacji staje się problem i część seniorów zmuszonych jest ograniczyć mobilność, a ograniczenie aktywności fizycznej może mieć wpływ na spadek samodzielności w późniejszym okresie.

Druga grupę seniorów stanowią osoby, które ze względu na niski stopień samodzielności wymagaja pomocy i wsparcia w codziennym funkcjonowaniu. W systemie pomocy społecznej wyróżnić możemy trzy główne formy zabezpieczenia potrzeb mieszkaniowych niesamodzielnych osób starszych, które nie mogą liczyć na opiekę sprawowaną przez opiekunów nieformalnych - rodzinnych: mieszkania wspomagane, chronione oraz domy pomocy społecznej.

Interesujacym rozwiązaniem dla seniorów o wysokim stopniu samodzielności sa mieszkania specjalnie dla nich projektowane, realizowane w ramach prywatnych inwestycji. Pierwszy tego typu lokal w Polsce powstał w Warszawie $^{10}$. Mieszkanie zostało zaprojektowane, wybudowane i wyposażone w taki sposób, by jak najdłużej umożliwić osobie starszej samodzielne funkcjonowanie bez konieczności wsparcia ze strony opiekunów. Lokal został przygotowany zgodnie z koncepcją promowaną w krajach Unii Europejskiej ageing in place, która zakłada, że w celu ograniczania kosztów długoterminowej opieki instytucjonalnej należy przygotować mieszkania, w których osoby starsze będą mogły jak najdłużej samodzielnie funkcjonować ${ }^{11}$. Koszt przystosowania modelowego mieszkania o powierzchni $50 \mathrm{~m}^{2}$ dla osób starszych wyniósł 160000 zł i obejmował pracę wykończeniowe, zakup mebli i urządzeń pomocniczych oraz pełnego wyposażenia. Całkowity koszt takiego mieszkania uzależniony jest od ceny lokalu (w stanie deweloperskim), do którego należy doliczyć wydatki na przystosowanie mieszkania na potrzeby seniorów ${ }^{12}$.

W przypadku seniorów, którzy zachowują samodzielność, a wymagają jedynie wsparcia i pomocy w codziennym funkcjonowaniu, rozwiązaniem moga być mieszkania wspomagane. Sa to lokale mieszkalne przystosowane do ich potrzeb. W budynkach z tego typu nie występuja bariery architektoniczne, które stanowiłyby utrudnienia w codziennym funkcjonowaniu dla osób niepełnosprawnych. Seniorzy moga korzystać ze wsparcia udzielanego przez opiekunki środowiskowe. Mieszkania przeznaczone są dla osób, które ukończyły 65 rok życia i nie posiadają innego lokalu na własność. Osoby starające się o najem mieszkania wspomaganego muszą wykazać, że dysponują dochodem pozwalającym na utrzymanie lokalu (czynsz, media itp.) i nie mają zadłużenia w opłatach za inny lokal mieszkalny (przykładowo z zasobów gminy).

${ }^{10}$ Wzorcowe mieszanie seniora, <www.mimowieku.pl>.

${ }^{11}$ A. Cieśla, Wzorcowe Mieszkanie Seniora na warszawskich Bielanach - pierwszy $w$ Polsce przyktad realnego, kompletnego, dedykowanego seniorom mieszkania, „Srebrna Gospodarka szansą dla Małopolski”, Małopolskie Studia Regionalne 2017, nr 1/35, s. 66.

12 Wzorcowe mieszanie seniora, <www.mimowieku.pl>. 
W 2015 r. w Szczecinie wybudowano 23 mieszkania wspomagane. Inwestycja została zrealizowana przez Gminę Szczecin i Szczecińskie Towarzystwo Budownictwa Społecznego. Do użytku oddano 23 lokale, 6 z nich to mieszkania jednopokojowe, 16 - dwupokojowe i 1 - trzypokojowe. Czynsz w mieszkaniach wspomaganych zbliżony jest do czynszu za lokale w zasobach gminy i w przypadku mieszkań o powierzchni $40 \mathrm{~m}^{2}$ wynosi ok. 619,70 zł dla jednej osoby. Jeśli lokal zamieszkują dwie osoby, czynsz określony został na poziomie 689,20 zł. Mieszkania przeznaczone są dla osób wieku 65 i więcej lat, które nie mają tytułu prawnego do lokalu mieszkalnego, domu jednorodzinnego lub działki budowlanej. Senior, który chce zamieszkać w mieszkaniu wspomaganym, musi uzyskiwać dochód wysokości co najmniej 1400 zł w przypadku gospodarstwa jednoosobowego i nie wyższy niż 3014,44 zł, w przypadku gospodarstwa dwuosobowego - minimalnie $2100 \mathrm{zł}$ i maksymalnie 4521,66 zł ${ }^{13}$.

Mieszkania chronione przeznaczone sa dla seniorów o niskim stopniu samodzielności, którzy wymagają opieki całodobowej realizowanej przez opiekunki środowiskowe. Na mieszkania chronione najlepiej nadają się lokale o powierzchni około $100 \mathrm{~m}^{2}$, w których skład wchodzą trzy sypialnie, pokój dzienny, kuchnia oraz łazienka lub łazienki. W każdym z pokoi mieszkalnych powinno przebywać dwoje mieszkańców, co pozwala na zapewnienie minimum intymności. Przebywanie w jednym mieszkaniu chronionym 4 lub 6 mieszkańców pozwala na zabezpieczenie usług opiekuńczych przez całą dobę, realizowanych przez pracowników ośrodków pomocy społecznej lub firm wyłonionych w konkursach w ramach realizacji zadań zleconych przez gminę $e^{14}$. Warto pokreślić, że w mieszkaniach chronionych można uzyskać wskaźnik opiekuńczy nieosiagalny $\mathrm{w}$ formach instytucjonalnych. W tego typu lokalach jeden opiekun świadczy usługi i udziela wsparcia 5-6 seniorom. W przypadku domów pomocy społecznej średnio na jednego pracownika działu opiekuńczego przypada około 17 mieszkańców ${ }^{15}$.

W Szczecinie w ostatnich latach utworzono pięć mieszkań chronionych. Średni koszt utworzenia jednego mieszkania chronionego, w którym zamieszkało sześciu seniorów, wyniósł 102040 zł. Natomiast roczny koszt utrzymania (czynsz, fundusz remontowy oraz media) wyniósł 20500 zł. Dodatkowo należy uwzględnić wydatki na usługi opiekuńcze, które dla 6 seniorów o niskim stopniu samodzielności kształtują się w ujęciu rocznym na poziomie 184464 zł16.

Osoby starsze przejawiające znikomą samodzielność, niemogące liczyć na wsparcie ze strony członków rodziny, mogą uzyskać świadczenia w domach pomocy społecznej (DPS). Aktualnie w placówkach tego typu przebywają osoby przewlekle somatycznie lub psychicznie chore oraz osoby starsze. Według danych Ministerstwa Rodziny, Pracy i Polityki Społecznej 13\% mieszkańców DPS stanowią osoby nieopuszczające łóżek ${ }^{17}$. W kolejnych latach można spodziewać się wzrostu liczby mieszkańców DPS, którzy prowadzić będa

\footnotetext{
${ }_{13}$ Miejski Ośrodek Pomocy Rodzinie w Szczecinie, 2016.

${ }^{14}$ Miejski Ośrodek Pomocy Rodzinie w Szczecinie, 2016.

15 R. Iwański, Opieka dtugoterminowa nad osobami starszymi, Warszawa 2016, s. 151.

16 Miejski Ośrodek Pomocy Rodzinie w Szczecinie, 2016.

17 Raport MPiPS-05, Ministerstwo Rodziny Pracy i Polityki Społecznej, 2016.
} 
leżący tryb życia. Istnieją jednak sytuacje, w których skierowanie do DPS otrzymuja osoby samodzielne, ale orzeczenia takie wydawane są z przyczyn socjalnych.

Z uwagi na doniosłość kwestii starzenia się społeczeństwa i znaczenia mieszkania w życiu każdego człowieka autorzy uznali, że społeczne budownictwo mieszkaniowe (SBM) jako specyficzny segment budownictwa mieszkaniowego może stanowić duży potencjał w celu rozwiązania narastających problemów. Ponieważ w ramach SBM możliwe jest dostarczanie indywidualnych, tanich i dostępnych mieszkań, istotna więc wydaje się konieczność zachowania przynajmniej częściowej samodzielności przez seniorów chcących skorzystać z tego typu pomocy mieszkaniowej.

\section{ZNACZENIE MIESZKANIA W ŻYCIU CZŁOWIEKA}

Mieszkanie jako jedno z najdroższych dóbr konsumpcyjnych stanowi składnik majątku rodziny, ale jest również miejscem, w którym każdy człowiek zaspokaja swoje potrzeby, poczynając od potrzeb podstawowych, według klasyfikacji A. Maslowa - takich jak fizjologiczne, poprzez potrzeby bezpieczeństwa i przynależności, na samorealizacji kończac. Mieszkanie umożliwia jednostkom zabezpieczenie przed zmieniającymi się warunkami zewnętrznymi, przygotowywanie i spożywanie posiłków, poczucie prywatności, wyodrębnienie swoich od obcych, prokreację, realizowanie pasji i obowiązków, w tym zawodowych. Niezaspokojenie potrzeby mieszkaniowej prowadzi do wielu dysfunkcji, wśród ludzi młodych ogranicza możliwość rozwoju rodziny, daje poczucie braku stabilizacji i bezpieczeństwa socjalnego ${ }^{18}$. Natomiast wśród osób w późniejszym wieku, także wśród seniorów, brak mieszkania, w tym także dostosowanego do potrzeb jednostkowych, ogranicza utrzymywanie więzi społecznych, prowadzi do wykluczenia społecznego, obniża jakość życia i prowadzi do ograniczenia realizacji innych ważnych potrzeb związanych z samodzielną egzystencja.

Na znaczenie mieszkania wskazują liczne akty prawne zarówno o zasięgu krajowym, jak i międzynarodowym, gwarantujące dostęp do niego, m.in. Powszechna deklaracja praw człowieka ONZ z 1948 r., Pakt praw gospodarczych, społecznych i kulturalnych z 1966 r., Deklaracja postępu społecznego i rozwoju z 1969 r. czy Międzynarodowa konwencja o prawach dziecka z 1989 r. ${ }^{19}$

Według danych z Narodowego Spisu Powszechnego w 2011 r. w Polsce nie występuje deficyt ilościowy mieszkań. Liczba mieszkań przekracza liczbę gospodarstw domowych. Wskazać jednak należy, że mamy do czynienia z deficytem jakościowym - wiele mieszkań jest niezamieszkanych z powodu sta-

${ }^{18}$ G. Główka, System finansowania nieruchomości mieszkaniowych w Polsce: doświadczenia i kierunki zmian, Warszawa 2012, s. 18.

19 Z. Rataj, Społeczne budownictwo mieszkaniowe i jego rola w zaspokajaniu potrzeb mieszkaniowych niezamożnych gospodarstw domowych $w$ Polsce, niepublikowana praca doktorska, UEP, Poznań 2015. 
nu technicznego, a liczba mieszkań substandardowych stale utrzymuje się na wysokim poziomie (według Narodowego Spisu Powszechnego z 2011 - 1,3 mln mieszkań ${ }^{20}$ ). Duża część tych mieszkań znajduje się w zasobach gmin - komunalnych i socjalnych, co powoduje, że osoby w trudnej sytuacji materialnej bądź zdrowotnej muszą korzystać z gorszych jakościowo lokali. Problem ten staje się istotny w kontekście rosnącej liczby seniorów, którzy w najbliższej przyszłości będą potrzebować mieszkań dostosowanych do ich potrzeb z uwagi na niewystarczającą liczbę miejsc w domach pomocy społecznej. Okres przebywania seniorów w DPS (w szczególności w domach dla osób przewlekle psychicznie chorych) wydłuża się, co powoduje zmniejszoną rotację ich mieszkańców. W związku z tym zapotrzebowanie na mieszkania wspomagane, chronione i specjalnie zaprojektowane będzie rosło. Autorzy uznaja, że możliwy do wykorzystania potencjał w celu zaspokojenia potrzeb mieszkaniowych osób starszych znajduje się w społecznym budownictwie mieszkaniowym.

\section{SPOŁECZNE BUDOWNICTWO MIESZKANIOWE}

Społeczne budownictwo mieszkaniowe w ujęciu międzynarodowym nie ma jednolitej definicji. Christian Donner, badacz polityki mieszkaniowej w krajach Unii Europejskiej, wskazuje, że budownictwo społeczne może przyjmować różna postać. W niektórych krajach są to zasoby całkowicie dotowane, w innych natomiast za społeczne uznaje się mieszkania zarówno komunalne (ang. public housing), jak i czynszowe o umiarkowanym zysku (ang. limited-profit housing). Autor zauważa również, że niekiedy do zasobów społecznych włącza się również podsektor prywatny, pod warunkiem utrzymania stawek czynszów poniżej poziomu rynkowego w wyniku interwencji publicznej. Mieszkania dostarczane sa przez podmioty publiczne, w tym gminy oraz podmioty prywatne - deweloperów, którzy jednak nie mają pełnej swobody w kształtowaniu poziomu czynszów ${ }^{21}$. Interesujace podejście do definicji budownictwa społecznego przedstawia Jim Kemeny ${ }^{22}$. W na podstawie sposobów ustalania poziomu czynszów podzielił budownictwo na sektor czynszowy dla zysku oraz sektor czynszowy non for profit. Podmioty ustalające stawkę czynszu na poziomie wartości odtworzeniowej lokalu traktuje jako działające nie dla zysku, bez względu na to, czy sa to podmioty publiczne czy prywatne. Podmioty maksymalizujące zysk z posiadanej nieruchomości mieszkaniowej, a więc działajace dla zysku, reprezentowane są najczęściej przez instytucje prywatne.

Analiza definicji budownictwa społecznego w różnych krajach pozwala zauważyć wiele zmiennych warunkujacych rozwój i kształtujących jego cha-

${ }^{20}$ GUS, Wyniki Narodowego Spisu Powszechnego Ludności i Mieszkań 2011. Podstawowe informacje o sytuacji demograficzno-społecznej ludności Polski oraz zasobach mieszkaniowych, Warszawa 2013.

21 Ch. Donner (ed.), Housing Policies in Central Eastern Europe, Vienna 2006.

22 J. Kemeny, Theories of power in Three Worlds of Welfare Capitalism, „Journal of European Social Policy” 5(2), 1995. 
rakter; są to m.in. sposoby finansowania, poziom czynszów czy występowanie subsydiowania. Cechą wspólną charakterystyczną dla większości krajów jest sposób przydziału lokali, który odbywa się zazwyczaj z pominięciem mechanizmów rynkowych. Główną zasadą dysponowania mieszkaniami z zasobów społecznych jest kryterium potrzeb, a w dalszej kolejności zdolność do regulowania czynszów. W związku z tym kierowane są one do różnych grup gospodarstw domowych (w zależności od kraju). Najczęściej są to jednak gospodarstwa najbiedniejszych grup społecznych, a także o niskich i średnich dochodach.

W Polsce społeczne budownictwo mieszkaniowe to część sektora mieszkaniowego wyodrębniona z rynku komercyjnego; dzięki różnym formom dofinansowania inwestycji oraz utrzymania i użytkowania mieszkań charakteryzuje się ono niższymi opłatami ponoszonymi przez gospodarstwa domowe. Zakwalifikowanie lokalu do zasobów społecznych wymaga spełnienia kilku warunków:

- produkcja i/lub koszty finansowania obejmują ograniczony zysk lub sa częściowo pokryte publicznymi lub prywatnymi subsydiami;

- płacona cena za mieszkanie lub płacony czynsz najmu powinny się kształtować poniżej poziomu rynkowego, ale nie oznacza to, że poniżej kosztu;

- efekt subsydiowania powinien stanowić pożytek dla gospodarstw o niskich i bardzo niskich dochodach ${ }^{23}$, które nie mają możliwości zaspokojenia swoich potrzeb mieszkaniowych na wolnym rynku.

Wsparcie SBM środkami publicznymi dostępne jest zarówno na etapie budowy, jak i użytkowania mieszkań ${ }^{24}$, a ciężar realizacji inwestycji w zakresie SBM spoczywa na gminach i towarzystwach budownictwa społecznego.

Autorzy badajacy sytuację mieszkaniową w Polsce podkreślaja, że mieszkalnictwo społeczne to obszar funkcjonujaccy w ramach polityki mieszkaniowej, obejmujacy sektor otrzymujacy wsparcie państwa, samorządu terytorialnego lub innych podmiotów publicznych. Maciej Cesarski z mieszkalnictwem społecznym utożsamia bezpośrednio społeczną politykę mieszkaniowa, która związana jest z redystrybucją dochodów na rzecz wspomagania konsumpcji usług mieszkaniowych przez mniej zamożne grupy ludności ${ }^{25}$. Szeroka definicję społecznego budownictwa mieszkaniowego znajdujemy w pracy Anny Szelagowskiej Finansowanie społecznego budownictwa mieszkaniowego ${ }^{26}$; SBM uważa ona za typ budownictwa (formy mieszkalnictwa) kierowanego do niezamożnych (o niskich i średnich dochodach) gospodarstw domowych, które w całości lub w części jest finansowane ze środków publicznych, a w niektórych przypadkach także z prywatnych, pod warunkiem podpisania przez ich właścicieli specjalnej umowy z lokalnymi władzami samorządowymi.

${ }^{23}$ W. Dominiak, Realizacja społecznych celów mieszkalnictwa w krajach Unii Europejskiej. Implikacje dla Polski, w: L. Frąckiewicz, Przeszłość i przyszłość polskiej polityki mieszkaniowej, Warszawa 2005, s. 20.

${ }^{24}$ A. Muczyński, Gospodarowanie gminnymi zasobami lokalowymi z perspektywy polityki mieszkaniowej, „Studia i Materiały Towarzystwa Naukowego Nieruchomości” 19, 2011, nr 2.

${ }^{25}$ M. Cesarski, Polityka mieszkaniowa w Polsce w pracach naukowych 1918-2010. Dokonania i wptyw polskiej szkoty badań, Warszawa 2013, s. 14.

${ }^{26}$ Warszawa 2011. 
Społeczne budownictwo mieszkaniowe z uwagi na cechy mu przypisane może być wykorzystane jako instrument zaspokajania potrzeb mieszkaniowych osób starszych, w szczególności z uwagi na niższe koszty produkcji i użytkowania tych mieszkań, a także możliwość dostosowania mieszkań do potrzeb seniorów.

\section{MOŻLIWOŚĆ ZASPOKOJENIA POTRZEB MIESZKANIOWYCH SAMODZIELNYCH SENIORÓW PRZEZ SPOŁECZNE BUDOWNICTWO MIESZKANIOWE}

Główne cele polityki mieszkaniowej zapisane w Konstytucji Rzeczypospolitej Polskiej związane sa z zaspokojeniem potrzeb mieszkaniowych wszystkich obywateli, przeciwdziałaniem bezdomności, wspieraniem rozwoju budownictwa socjalnego oraz popieraniem działań obywateli zmierzających do uzyskania własnego mieszkania ${ }^{27}$. Szczególną troską otaczane są grupy wrażliwe, takie jak: osoby niepełnosprawne, rodziny wielodzietne, samotni rodzice, wychowankowie domów dziecka, osoby opuszczające instytucje karne i zakłady poprawcze oraz osoby starsze. Z uwagi na sytuację zawodową oraz zdrowotna osób starszych, w opinii autorów niniejszego opracowania, seniorzy stanowia jedną z najbardziej zagrożonych wykluczeniem mieszkaniowym grup.

Populacja osób starszych jest mocno zróżnicowana wewnętrznie. Przejawia się to m.in. w aspekcie jednostkowych potrzeb, możliwości, aspiracji, upodobań, deficytów oraz kondycji psychofizycznej i ekonomicznej ${ }^{28}$. Po pierwsze, sa to osoby w wieku emerytalnym, nierzadko wykluczającym możliwość dodatkowej pracy zarobkowej, a więc mają ograniczone dochody, uwarunkowane bardzo często wcześniejszą karierą na rynku pracy. Powoduje to, że potrzebuja one mieszkań dostępnych cenowo, których użytkowanie będą w stanie opłacić, bez popadania w długi i nie będą zagrożeni eksmisją z tytułu należności czynszowych. Po drugie, z uwagi na wiek i choroby z nim związane seniorzy potrzebują mieszkań dostosowanych do indywidualnych potrzeb. Część osób ma ograniczoną możliwość poruszania się, inne potrzebują specjalistyczny balkoników czy niekiedy wózków inwalidzkich, mimo pełnej sprawności intelektualnej i zdolności do samodzielnego życia w swoim mieszkaniu. Kierowanie samodzielnych osób starszych, zdolnych do codziennego funkcjonowania w środowisku lokalnym, do DPS może powodować izolację, wyłączenie z życia kulturalnego i towarzyskiego, a w konsekwencji poczucie bycia niepotrzebnym. Powyższe przesłanki powinny być podstawą tworzenia dostępnych form mieszkalnictwa dla osób starszych.

Najistotniejszym czynnikiem różnicujacym formę pomocy mieszkaniowej dla seniorów wydaje się ich niezależność i stopień samodzielności. Według

${ }^{27}$ Art. 75 Konstytucji Rzeczypospolitej Polskiej z 2 kwietnia 1997 r., Dz. U. 1997, Nr 78, poz. 483.

${ }^{28}$ E. Trafiałek, Innowacyjna polityka senioralna XXI wieku, między ateizmem, bezpieczeństwem socjalnym $i$ active ageing, Toruń 2016, s. 213. 
badań przeprowadzonych przez Centrum Badania Opinii Publicznej seniorzy preferują samodzielne życie (64\% badanych), a także wykazują niechęć do zamieszkiwania w kolektywach mieszkaniowych ${ }^{29}$. Ponadto badania prowadzone w Polsce wskazuja, że seniorzy niechętnie zmieniaja miejsce zamieszkania ${ }^{30}$. Środowisko mieszkaniowe stanowi dla seniorów, podobnie jak i dla młodszych grup ludności, ważne element życia z uwagi na czas spędzany w mieszkaniu i jego okolicy ${ }^{31}$.

Aby zapobiegać wykluczeniu mieszkaniowemu osób starszych, rozumianemu również jako zajmowanie mieszkań o niskim standardzie (tzn. bez koniecznych udogodnień, takich jak na przykład winda czy kabina prysznicowa bez progu) i jednocześnie umożliwiać seniorom dalsze życie w swoim środowisku, gminy powinny poszukiwać nowych rozwiązań z zakresu tworzenia mieszkań wspomaganych, chronionych i specjalnie dla nich projektowanych. Właściwie zaprojektowane środowisko mieszkaniowe wpływa bowiem na fizjologiczne, społeczne i funkcjonalne aspekty starzenia się ${ }^{32}$. Środowisko mieszkaniowe seniorów powinno maksymalizować ich niezależność, umożliwiać pełny udział w społeczeństwie, zapewniać usługi opiekuńcze, stwarzać możliwości samorealizacji oraz zwiększać poczucie godności ${ }^{33}$. Mieszkalnictwo senioralne stanowi specyficzny sektor, w którym wyróżnia się różne formy lokali mieszkalnych dla osób po przekroczeniu określonego wieku. Mieszkania skierowane do tej grupy ludności mogą występować jako pojedyncze lokale o określonej formie lub jako kombinacja kilku form w jednym miejscu (np. w budynku znajdować się mogą zarówno lokale specjalnie zaprojektowane, jak i wspomagane). $\mathrm{Z}$ uwagi na specyfikę społecznego budownictwa mieszkaniowego i przypisane jemu atrybuty autorzy upatrują w nim możliwości odpowiedzi na zgłaszane przez seniorów potrzeby i przynajmniej częściowego rozwiązania problemu wykluczenia mieszkaniowego osób starszych.

Społeczne budownictwo mieszkaniowe realizowane w Polsce w głównej mierze przez gminy i Towarzystwa Budownictwa Społecznego (TBS) finansowane jest ze środków własnych tych podmiotów, subwencji i w przypadku TBS - wkładu partycypacyjnego przyszłych lokatorów. Co do zasady w lokalach znajdujących się w zasobach gmin i TBS czynsze są ustalone na określonym poziomie: $\mathrm{w}$ przypadku gmin sa to zazwyczaj czynsze poniżej poziomu rynkowego, natomiast w przypadku TBS są one wyższe, z uwagi na konieczność spłaty zobowiązań kredytowych wobec Banku Gospodarstwa Krajowego, które zaciągnęły towarzystwa na budowę nowych lokali. Wysokość czynszu

${ }^{29}$ W. Brzeski, K. Kirejczyk ,E. Kozłowski, Perspektywy rozwoju budownictwa senioralnego $w$ Polsce, REAS, 2014, s. 20. Zob. <http://www.kongresbudownictwa.pl/pliki/reas\%20perspektywy\%20rozwoju\%20budownictwa\%20senioralnego.pdf> [dostęp: 11.10.2017].

${ }^{30} \mathrm{H}$. Gawron et al., Potrzeby mieszkaniowe klientów na lokalnym rynku nieruchomości mieszkaniowych $i$ sposoby ich zaspokajania (na przyktadzie Poznania), Poznań 2012, s. 112.

${ }_{31}$ M. Boruta, Gerontechnologia jako narzędzie w procesie zaspokajania potrzeb mieszkaniowych seniorów, „Progres in Economic Science” 2017, nr 4, s. 35.

${ }^{32}$ D.Y. Carstens, Site Planning and Design For the Elderly: Issues, Guidelines, and Alternatives, New York 1985, s. 10.

${ }_{33}$ J. Sandhu, An integrated approach to universal design: toward the inclusion of all ages, cultures, and diversity, w: W.F.E. Presier, E. Ostroff (eds.), New York 2001, s. 10. 
w mieszkaniach TBS nie może w skali roku przekraczać 4\% wartości odtworzeniowej lokalu. Mimo że stawki za opłaty mieszkaniowe w TBS znacząco odbiegają od tych na poziomie gmin, towarzystwa gwarantuja stabilny najem długoterminowy ${ }^{34}$. Dostępność cenowa mieszkań wydaje się istotnym czynnikiem warunkującym zaspokojenie potrzeb mieszkaniowych seniorów z uwagi na ograniczone źródła dochodów i świadczeń, które mogą otrzymywać osoby starsze, oraz zwiększone potrzeby zdrowotne i wydatki na nie. W przypadku mieszkań z zasobów społecznych gminy mają możliwość regulacji czynszu w zależności od standardu mieszkania i sytuacji życiowej gospodarstwa domowego. Tworzenie mieszkań chronionych, wspomaganych czy specjalnie zaprojektowanych w zasobie społecznym, z uwagi na zamieszkiwanie w nich kilku osób starszych, obniżyłoby ich koszty utrzymania i jednocześnie seniorzy mieliby kontakt z osobami w podobnym wieku. Ponadto tworzenie w jednym budynku kilka mieszkań przeznaczonych dla seniorów, również obniża koszty zarządzania nimi. Warto również wspomnieć o aspekcie opiekuńczym: dzięki skupieniu w jednym miejscu kilka lokali mieszkalnych opiekunki zajmujące się wsparciem seniorów mogłyby być dostępne dla potrzebujacych wsparcia w większym wymiarze czasu, bez konieczności przemieszczania się między różnymi lokalizacjami w mieście.

Społeczne budownictwo mieszkaniowe, w szczególności tworzone w systemie TBS, daje możliwość aranżacji przestrzeni. Z uwagi na zaangażowanie towarzystw w tworzenie budynków mogą one przeznaczyć lokale na mieszkania dla seniorów już na etapie budowy, co umożliwi ich dostosowanie architektoniczne na poziomie projektowania i realizacji przedsięwzięcia budowlanego. Przykładem może być zrealizowany przez Poznańskie Towarzystwo Budownictwa Społecznego pionierski program „Mieszkanie dla seniora”, w ramach którego powstał w 2009 r. Dom Seniora, a w 2012 r. - Środowiskowy Dom Emeryta. Obie inwestycje powstały w ramach miejskiego programu „Seniorzy”, wpisanego do „Planu Rozwoju Miasta Poznania na lata 2005-2010” w ramach priorytetu „Obywatelski Poznań”.

Dom Seniora to kompleks dwóch budynków czteropiętrowych. W jego skład wchodzą mieszkania dwu- i jednopokojowe, zgodnie z zasadami funkcjonowania TBS, w całości przeznaczone na wynajem. Mieszkańcy inwestycji maja do dyspozycji parking podziemny oraz naziemny. Dom ten został zaprojektowany w taki sposób, aby umożliwić integrację mieszkańców. Dlatego też w ramach kompleksu zaprojektowano przestrzeń do wspólnego użytkowania, a na przylegającym do budynków terenie zielonym postawiono murowany grill zewnętrzny, zaciszną altanę oraz siłownię ${ }^{35}$. Inwestycja jest ulokowana w pobliżu sklepów, kościoła, ogródków działkowych, przychodni lekarskich oraz

${ }^{34}$ Często stawki czynszu w TBS są niższe niż ceny najmu na rynku prywatnym, dlatego że towarzystwa nie pobierają dodatkowych opłat za użytkowanie mieszkania, jak czynią to prywatni właściciele, którzy oprócz czynszu do spółdzielni mieszkaniowych pobierają wysokie opłaty za najem mieszkania. W wielu miastach miesięczne opłaty za mieszkanie na rynku prywatnym przekraczaja poziom raty kredytu mieszkaniowego (Z. Rataj, op. cit.).

35 Poznańskie Towarzystwo Budownictwa Społecznego, <http://ptbs.pl/oferta/mieszkanie-dlaseniora/> [dostęp: 12.10.2017]. 
apteki. Co jest bardzo istotne, osiedle jest dobrze skomunikowane $\mathrm{z}$ centrum miasta, a przystanek autobusowy i tramwajowy znajduja się $\mathrm{w}$ jego pobli$\dot{z ̇ u}$, dlatego też seniorzy mają dobry dostęp do centrów kulturalnych. W jednym z budynków ma również swoją siedzibę Stowarzyszenie Ludzi III Wieku „Świerczewski Krag”, którego celem jest aktywizacja fizyczna i intelektualna seniorów.

W Środowiskowym Domu Seniora powstało 68 samodzielnych mieszkań jedno-, dwu- i trzypokojowych; 50 mieszkań dostosowanych było do potrzeb osób niepełnosprawnych, natomiast w większości mieszkań zastosowano rozwiązania eliminujące progi i różnice poziomów podłogi. Na parterze budynku znajdują się gabinety: lekarski oraz zabiegowy, a w kondygnacji podziemnej hala garażowa dla mieszkańców. Korytarze są szerokie i umożliwiają swobodną komunikację mieszkańców. Ponadto w budynku znajdują się trzy windy, z czego jedna umożliwia przewożenie osób w pozycji leżącej. Co jest interesujące, PTBS zadbało również o część integracyjno-wypoczynkową zarówno wewnątrz budynku, jak i na zewnątrz. Przed wejściem usytuowano szachownicę do gry z dużymi figurami. Ten rodzaj budownictwa wpisuje się w koncepcje mieszkań wspomaganych dla seniorów ${ }^{36}$.

Wzorcowe Mieszkania Seniora to warszawska inwestycja, która została przeprowadzona w wyniku oddolnej inicjatywy - jak mówią sami mieszkańcy - miasto nie było zainteresowane współudziałem w przedsięwzięciu. $\mathrm{W}$ ramach tego projektu powstał wielorodzinny budynek zaprojektowany w taki sposób, aby był dostępny dla przyszłych mieszkańców zarówno pod względem architektonicznym, jak i finansowym. Wszystkie pomieszczenia uwzględniają potrzeby osób poruszających się na wózkach inwalidzkich, natomiast szczególną wagę przywiązano do łazienek wyposażając je w przestawną umywalkę, siedzisko pod prysznicem oraz uchwyty. Założeniem twórców tego modelowego budynku było zapewnienie seniorom możliwości starzenia się we własnym miejscu zamieszkania ${ }^{37}$. Jest to dobrze funkcjonująca inicjatywa, która może być nie tylko przykładem modelu mieszkań specjalnie zaprojektowanych dla seniorów, lecz także być wzorem mieszkań dostępnych (affordable housing) dla podmiotów polityki mieszkaniowej. Istotne jest, aby gminy dostrzegły potencjał takich miejsc i angażowały się we wsparcie procesu realizacji podobnych inwestycji, z uwagi na ograniczony zasób własnych mieszkań, które mogą być przekazane do użytku osobom w podeszłym wieku. Jeśli gminy nie mają możliwości całkowitego zaangażowania się w podobne projekty, pomoc może przejawiać się w postaci udostępniania gruntów czy obniżania kosztów ich zakupu dla inicjatyw oddolnych bądź partnerstw publiczno-prywatnych. Zaznaczyć należy, że inicjatywy oddolne stanowią dobrą alternatywę dla rynku prywatnego, ponieważ pomijają wszelkie usługi związane $\mathrm{z}$ działalnościa deweloperska, w tym promocja, co obniża koszty finalne inwestycji budowlanych nawet o $20-30 \%$.

${ }^{36}$ Zob. <http://ptbs.pl/inwestycja-zrealizowana/ul-grabowa/> [dostęp: 12.10.2017].

${ }^{37}$ Zob. <http://mimowieku.pl/> [dostęp: 12.10.2017]. 


\title{
VII. PODSUMOWANIE
}

Starzenie się społeczeństwa polskiego stanowi wyzwanie dla osób odpowiedzialnych za politykę społeczna, w tym mieszkaniowa; są one odpowiedzialne za tworzenie otoczenia sprzyjającego zaspokojeniu potrzeb osób w starszym wieku. Rosnące wydatki na opiekę nad osobami starszymi wskazują na konieczność poszukania odpowiednich rozwiązań umożliwiajacych samodzielnym lub częściowo samodzielnym seniorom zamieszkiwanie w swoim środowisku mieszkaniowym. Duże zróżnicowanie wewnętrzne grupy osób w wieku 65+ pod kątem ich sprawności, niezależności i stanu zdrowia wymusza na polityce mieszkaniowej poszukiwania rozwiązań umożliwiających realizację potrzeb mieszkaniowych na poziomie dostosowanym do potrzeb poszczególnych grup. Cele pracy zostały osiagnięte przez przedstawienie inwestycji przeprowadzonych w Poznaniu, Szczecinie i Warszawie, które dotyczyły mieszkalnictwa senioralnego skierowanego na zaspokajanie potrzeb osób starszych o ograniczonej samodzielności, zrealizowane przez władze samorządowe, towarzystwa budownictwa społecznego oraz podmioty ekonomii społecznej. Odpowiedzia na ten fakt jest tworzenie mieszkań specjalnie zaprojektowanych, chronionych i wspomaganych w ramach zasobów społecznych. Wykorzystywać należy nie tylko środki własne gminy, ale również zaangażować je we współpracę z towarzystwami budownictwa społecznego, chociażby przez przekazywanie gruntów pod budownictwo senioralne w postaci aportu. Umożliwi to budowanie mieszkań tańszych w użytkowaniu, o stabilnym najmie i dostosowanych do ograniczeń fizycznych wynikających z wieku dojrzałego. Autorzy uznaja, że segment społecznego budownictwa mieszkaniowego ma duży potencjał, który w kolejnych latach może być wykorzystany.

\author{
dr Zuzanna Rataj \\ Uniwersytet Ekonomiczny w Poznaniu \\ zuzanna.rataj@ue.poznan.pl \\ dr Rafat Iwański \\ Uniwersytet Szczecinski \\ rafal.iwanski@usz.edu.pl \\ dr hab. Beata Bugajska \\ Uniwersytet Szczecinski \\ beata.bugajska@usz.edu.pl
}

SOCIAL HOUSING IN THE LIGHT OF THE AGEING POLISH SOCIETY

\author{
Sum mary
}

The article discuss the consequences of demographic changes which have an influence on housing needs of elderly people. Population forecasts predict that in the nearest decades the number of senior citizens will rise, particularly in the category of those aged 85+. Due to the limited number of places in sheltered flats, residential homes or old people's homes, new solutions must be found to provide new housing unit for seniors. The needs of elderly people in 
the housing industry are diversified and depend on their social, psychological, biological or economic situation, and in particular on the degree of their independence or possibility of selfreliance. The importance of the place of living in the life of every man requires solving the problem. Social housing being a specific section of the housing market may have a great potential in solving housing problems for the elderly, especially when the lower costs of investments in the construction and maintenance of flats from this sector is taken into account. 